\title{
Characterization of phytoplankton by pigment analysis and the detection of toxic cyanobacteria in reservoirs with aquaculture production
}

\author{
Louise Schlüter ${ }^{1, *}$, Gianmarco S. David ${ }^{2}$, Niels O. G. Jørgensen ${ }^{3}$, Raju Podduturi ${ }^{3}$, \\ Andréa Tucci ${ }^{4}$, Andréa S. Dias ${ }^{4}$, Reinaldo José da Silva ${ }^{5}$ \\ ${ }^{1}$ Environment and Toxicology, DHI, 2970 Hørsholm, Denmark \\ ${ }^{2}$ São Paulo State Agribusiness Agency Technology at Jau, 17201-970, Brazil \\ ${ }^{3}$ Section of Microbial Ecology and Biotechnology, Department of Plant and Environmental Sciences, \\ University of Copenhagen, 1871 Frederiksberg, Denmark \\ ${ }^{4}$ Ficology Department, Botanical Institute, 04301-902, São Paulo, Brazil \\ ${ }^{5}$ UNESP Campus Botucatu, Institute of Biosciences, Parasitology Department, 18618-689 Botucatu, SP, Brazil
}

\begin{abstract}
The intensified use of water bodies and reservoirs for aquaculture production has increased the need for monitoring and early warning of toxins from cyanobacteria. To minimize effects from toxins, simple and fast analytical monitoring methods are crucial. Here, the content of pigments and microcystins in 14 different strains of cyanobacteria cultured under different growth conditions was investigated to determine the influence of light and nutrient starvation on pigment/chlorophyll a $(\mathrm{chl}$ a) ratios. The obtained pigment/chl a ratios were applied in the software CHEMTAX to calculate the biomass of toxic cyanobacteria, as well as other phytoplankton groups. CHEMTAX ratios from the laboratory cultures were applied to water samples collected during 4 sampling periods at 6 fish farms in different reservoirs in São Paulo State, Brazil. Cyanobacteria generally dominated in all reservoirs in all sampling periods and constituted on average 44 to $66 \%$ of the average phytoplankton biomass. The concentrations of microcystins were significantly correlated with the chl a concentrations of cyanobacteria and showed that the pigment method can be used to detect microcystin-producing cyanobacteria in these Brazilian reservoirs. When the concentration of cyanobacteria in the reservoirs was above $4 \mu \mathrm{g} \mathrm{chl} \mathrm{a} \mathrm{l}^{-1}$, microcystins were always detected. Our results show that pigment analysis can be used to provide fast and reliable results for the early warning, the presence and potential risk of toxic cyanobacteria in freshwater reservoirs used for aquaculture.
\end{abstract}

KEY WORDS: Microcystins - Pigment analysis - Cyanobacteria - Phytoplankton composition · HPLC · Fish farm

\section{INTRODUCTION}

Cyanobacteria are widely distributed and can form dense blooms in lakes and reservoirs in both temperate, subtropical, and tropical regions (Willén et al. 2011). Many species of cyanobacteria produce toxic compounds, which have been shown to cause serious

${ }^{*}$ Corresponding author: lsc@dhigroup.com health hazards for humans, livestock, and wildlife (Briand et al. 2003, Malbrouck \& Kestemont 2006). Current knowledge on harmful blooms of cyanobacteria and climate change suggests that future eutrophication is likely to enhance the magnitude and frequency of these events $\left(\mathrm{O}^{\prime} \mathrm{Neil}\right.$ et al. 2012). Aquaculture is a fast growing food sector, and

(C) The authors 2018. Open Access under Creative Commons by Attribution Licence. Use, distribution and reproduction are unrestricted. Authors and original publication must be credited. 
blooms of cyanobacteria may be the consequence of aquaculture production, since fish excreta and unassimilated feed can introduce eutrophic or hypereutrophic conditions into intensively operated fish farms (Smith et al. 2008). Many species of cyanobacteria are known to produce toxins. Among identified toxins are hepatotoxins (e.g. microcystins and nodularins), cytotoxins (e.g. cylindrospermopsin), neurotoxins (e.g. anatoxins and paralytic shellfish poisoning [PSP] toxins), dermatoxins, tumor promotors, irritant toxins, etc. (Smith et al. 2008). The hepatotoxins in particular remain in the flesh of aquatic animals for weeks after intake (Eriksson et al. 1989, Soares et al. 2004, Smith \& Haney 2006). Microcystins are toxic to fish by inhibiting protein phosphatases, leading to oxidative stress, reduced growth rates, and tumor promotion (Malbrouck \& Kestemont 2006, Smith et al. 2008). Although fish accumulate microcystin mainly in the liver, they also accumulate it in muscle tissue and viscera, which is a risk to humans who eat the fish (Magalhães et al. 2001, Soares et al. 2004). In some cases, the dietary intake values of microcystins in fish have been found to be above the limits determined by international legislations (Hauser-Davis et al. 2015, Gurbuz et al. 2016). In humans, microcystin may also promote cancer due to chronic exposure to low microcystin concentrations in drinking water and probably also from eating fish (Ueno et al. 1996, Zhou et al. 2002). In aquaculture production, microcystins are reported to cause fish mortality after the ingestion of cyanobacteria (Smith et al. 2008). Due to the intensified use of lakes and rivers for aquaculture production, there is a growing need for simple, yet accurate and precise analytical methods for monitoring the extent and species composition of algal blooms and for predicting the risk of toxic cyanobacteria.

The co-occurrence of different cyanobacterial species producing different toxins in lakes and reservoirs makes the prediction of toxin occurrence difficult. However, microcystins appear to contribute to more than $90 \%$ of the cyanotoxins detected in northern and middle European waters (Spoof et al. 2010), and microcystins also appear to be dominant toxins in many other parts of the world (Willén et al. 2011, Sant'Anna et al. 2008). Microcystins consist of 3 dominant toxin variants: the arginine-containing microcystins (MC)-RR, MC-YR, and MC-LR, with different degrees of methylation (Spoof et al. 2010). Many methods have been developed to detect microcystins, including the protein phosphatase inhibition assay, enzyme linked immunosorbent assay (ELISA), polymerase chain reaction (PCR), and various high performance liquid chromatography (HPLC) methods (Meriluoto et al. 2017). Among these methods, HPLC is the most commonly used analytical method, since it is fast and can detect several different microcystins at a detection limit well below the $1 \mu \mathrm{g} \mathrm{l}^{-1}$ limit for microcystins in drinking water published by the World Health Organization (WHO 1998).

Phytoplankton pigment analyses is a complementary method to traditional microscopy and is widely used in determining the composition and biomass of phytoplankton groups in both marine and in freshwater (Roy et al. 2011). Diagnostic pigments for specific algal groups, e.g. in natural waters, can be detected and quantified by HPLC at a low detection limit. The composition and chlorophyll a (chl a) biomasses of the algal classes can be calculated using, for example, the CHEMTAX program (Mackey et al. 1996, Wright et al. 1996). With this approach, cyanobacteria can be identified and quantified by their specific pigments in freshwater (Schlüter et al. 2006, 2016, Descy 2017).

The concentration of carotenoids and chl $a$ in phytoplankton are influenced by irradiance and nutrient limitation, and photosynthetically active pigments co-vary with chl a under conditions of changing irradiance, while light protecting pigments generally increase in relation to chl a during periods of increasing light and/or nutrient starvation (Schlüter et al. 2006). In the present study, the content of pigments and microcystins in several different strains of cyanobacteria cultured under different growth conditions was investigated using HPLC, to determine the influence of different light intensities and nutrient starvation on pigment/chl a ratios and on the toxin content. Pigment/chl a ratios were tested using the CHEMTAX program to calculate the biomass (as chl a) of cyanobacteria and other phytoplankton groups to evaluate the method for determining presence of toxic cyanobacteria at 6 fish farms in different Brazilian freshwater reservoirs. We hypothesized that, for the early warning of toxic cyanobacteria in freshwater reservoirs used for aquaculture, pigment analyses can provide fast and reliable results on the presence of cyanobacteria, and the method can be used to identify the risk of toxic cyanobacteria.

\section{MATERIALS AND METHODS}

\section{Development of $\mathrm{pigment/chl} \mathrm{a} \mathrm{ratios}$}

A total of 14 strains of cyanobacteria were selected for the culture experiment: Microcystis aeruginosa 
(National Institute for Environmental Studies, Japan) NIES-107, M. aeruginosa (Scandinavian Culture Collection [SCCAP], Denmark) K-0540, Microcystis sp. (Pasteur Culture Collection [PCC], France) PCC7820, M. botrys (SCCAP) K-0967, Microcystis sp. (isolated from the Brazilian reservoirs), Dolichospermum circinale (SCCAP) K-1333, D. lemmermannii (SCCAP) K-0544, Planktothrix cf. agardhii (synonymous Oscillatoria agardhii) (SCCAP) K-0546, P. rubescens (synonymous O. rubescens) (SCCAP) K0569, Planktothrix sp. 327/2 (Helsinki University Culture Collection, Finland), Pseudanabaena sp. (SCCAP) K-1230, Cylindrospermopsis raciborskii (isolated in Denmark), Pseudanabaena sp. (isolated from the Brazilian reservoirs), and Radiocystis sp. (isolated from the Brazilian reservoirs).

Cultures were grown at 3 different light intensities using Pope fluorescent tubes: low (LL), medium (ML) and high light (HL) as described in Schlüter et al. (2006). Briefly, the light intensity at LL, ML, and HL was 4,125 , and $275 \mu \mathrm{mol} \mathrm{E} \mathrm{m} \mathrm{m}^{-2} \mathrm{~s}^{-1}$, respectively. Cultures were maintained as semi-continuous batch cultures by daily replacing up to $50 \%$ of the algae culture with fresh medium to reach the initial cell density. Cultures were grown for $4 \mathrm{~d}$ to ensure acclimation to the given light intensity, and were harvested by filtering replicate 50 to $150 \mathrm{ml}$ subsamples on Whatman GF/C filters that were frozen instantly in liquid nitrogen. In order to test the effect of nutrient limitation, the ML cultures were not diluted until cell division ended (stationary growth, SG), at which point samples were also filtered. Samples for pigment analyses and microcystin analyses were extracted and analysed as described in the 'Pigment analysis' section.

\section{Sampling in reservoirs with fish farms}

Four sampling campaigns were carried out at fish farms with Nile tilapia Oreochromis niloticus in 3 reservoirs, built for water storage for hydroelectric power plants, in southeastern Brazil: Chavantes (1 farm, F1 with 2 farm areas, $1 \mathrm{a}$ and $1 \mathrm{~b} ; 2^{\circ} 08^{\prime}$ 33.9" S, 49 $34^{\prime} 24.7^{\prime \prime} \mathrm{W}$ ), Ilha Solteira (2 farms: F5 and F6; 20¹8' 46.2" S, 5110' 24.0"W), and Nova Avanhandava (3 farms: F2, F3, and F4; $21^{\circ} 08^{\prime} 24.0^{\prime \prime} \mathrm{S}$, $50^{\circ} 08^{\prime} 20.5^{\prime \prime} \mathrm{W}$ ) (Fig. 1). Two seasons were sampled twice: the beginning of spring and early autumn on the following dates: 30 October to 6 November 2014; 9 to 14 March 2015; 28 September to 3 October 2015; and 7 to 12 March 2016. Samples were taken at 3 points: upstream of the fish farms, inside the fish farms, and downstream of the fish farms, at a depth of $1 \mathrm{~m}$ using a Van Dorn water sampler. Farm F3 is located upstream to fish farm F4 in Nova Avanhandava, and consequently only one upstream and one downstream sample were taken for the 2 fish farms (i.e. F3+F4). For microscopic counting, the samples were preserved in acetic Lugol aqueous solution $(1 \%)$. For pigment and microcystin analyses, subsamples were filtered on Whatman GF/F filters, immediately frozen in liquid nitrogen, and kept frozen until analysis by HPLC as described in the 'Pigment analysis' section.

\section{Microscopy}

Quantitative analysis of phytoplankton followed the Utermöhl (1958) method using an inverted microscope and sedimentation chambers of 10 or $25 \mathrm{ml}$, de-

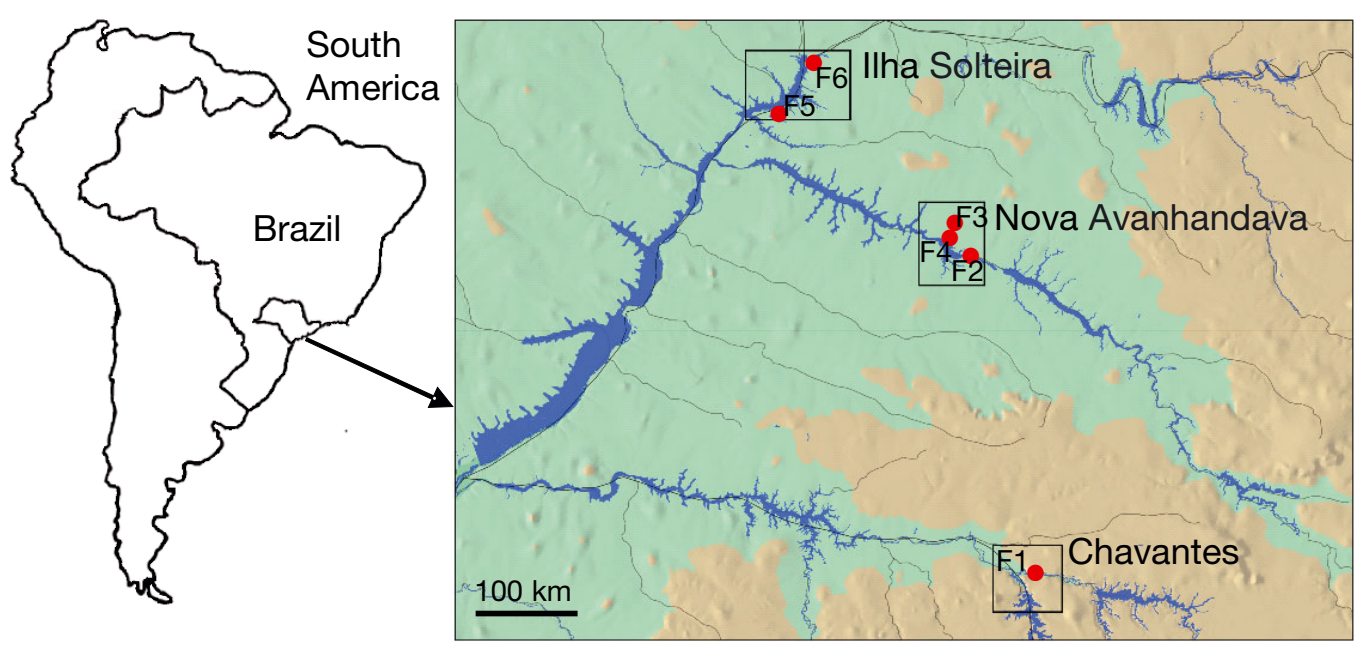

Fig. 1. Location of the reservoirs with the fish farms (red dots, F1-F6) in the main rivers of the upper Paraná basin, Brazil 
pending on the phytoplankton density in each sample. Sedimentation time was $4 \mathrm{~h} \mathrm{~cm}^{-1}$ (Lund et al. 1958). A counting limit was established through the species-rarefying curve and until reaching 100 individuals of the most common species. Phytoplankton was identified according to Bicudo \& Menezes (2017), Sant'Anna et al. (1989), Tucci et al. (2006) and references therein. Each cell, filament or colony was regarded as one individual and estimated as organisms (org.) $\mathrm{ml}^{-1}$ following UNESCO (2010) guidelines.

\section{Pigment analysis}

Filters for pigment analysis were extracted in $3 \mathrm{ml}$ $95 \%$ acetone with vitamin $\mathrm{E}$ acetate as an internal standard. The filters were sonicated in an ice-cool sonication bath for $10 \mathrm{~min}$, extracted further at $4^{\circ} \mathrm{C}$ for $20 \mathrm{~h}$ and mixed using a vortex mixer for $10 \mathrm{~s}$. The filters and cell debris were filtered from the extracts into HPLC vials using disposable syringes and $0.2 \mu \mathrm{m}$ Teflon syringe filters. Pigment analyses were carried out according to Schlüter et al. (2016) using the Van Heukelem \& Thomas (2001) method, but with an adjusted pump gradient to optimise the pigment resolution. More than 30 different phytoplankton carotenoids and chlorophylls can be detected. The HPLC was a Shimadzu LC10ADVP HPLC system composed of one pump (LC10ADVP), a photodiode array detector (SPD-M10AVP), a SCL-10ADVP system controller with Lab Solution software, a temperature controlled auto sampler (SIL10ADVP) (set at $4^{\circ} \mathrm{C}$ ), a column oven (CTO-10ASVP), and a degasser (ERC 3415a). The HPLC system was calibrated using pigment standards from DHI Lab Products. Peak identities were routinely confirmed by online photo diode array analysis.

\section{Toxin analysis}

Filters for toxin analyses were thawed and frozen 3 times, excess water was drained briefly between absorbing paper, and extracted in $1.0 \mathrm{ml} 75 \%$ methanol $(\mathrm{MeOH})$ with vitamin $\mathrm{E}$ acetate as an internal standard to adjust for residual water in the filter and solvent evaporation. The filters were sonicated on ice with a Sonics VCX 750W sonicator in pulse mode at a $40 \%$ duty cycle for $1 \mathrm{~min}$ with a 4 -element probe allowing simultaneous sonication of 4 samples. This step was repeated 3 times; the sonicator was cleaned in $75 \% \mathrm{MeOH}$ and dried in between each sonication. After each sonication step, the extracts were centrifuged at $10000 \times g$ for $10 \mathrm{~min}$, the supernatants
$(0.6 \mathrm{ml})$ were withdrawn, and $0.6 \mathrm{ml}$ extraction solvent was added. The combined supernatants $\left(1.8 \mathrm{ml}\right.$ in total) were evaporated to dryness at $60^{\circ} \mathrm{C}$ in a stream of nitrogen, dissolved in $0.4 \mathrm{ml} 75 \% \mathrm{MeOH}$, and finally re-filtered through $0.2 \mu \mathrm{m}$ Teflon syringe filters into HPLC vials. The HPLC was a Shimadzu LC-10ADVP system with 2 pumps (LC-10AS), an auto sampler (set at $4{ }^{\circ} \mathrm{C}$ ), and a column oven (set at $40^{\circ} \mathrm{C}$ ). The column was a Synergy, $4 \mu \mathrm{m}$ Fusion-RP Phenomenex, $150 \times 4.6 \mathrm{~mm}$ with a pre-column. The mobile phases were $0.05 \%$ aqueous trifluoro-acetic acid (TFA) (solvent A) and $0.05 \%$ TFA in acetonitrile (solvent $\mathrm{B})$. The gradient program was as follows: 0 min, $25 \% \mathrm{~B}_{\text {; }} 5 \mathrm{~min}, 60 \% \mathrm{~B}_{\text {; }} 10.5 \mathrm{~min}, 100 \% \mathrm{~B} ; 15 \mathrm{~min}$, $100 \% \mathrm{~B} ; 16 \mathrm{~min}, 25 \% \mathrm{~B} ; 23 \mathrm{~min}$, stop; with a flow rate of $1.3 \mathrm{ml} \mathrm{min} \mathrm{m}^{-1}$ and an injection volume of $50 \mu \mathrm{l}$. The internal standard eluted after about $15 \mathrm{~min}$ and did not co-elute with the microcystins. The HPLC was calibrated using microcystin standards from DHI Lab Products, and toxins were quantified at $238 \mathrm{~nm}$. Microcystins were detected by their retention times and absorption spectra by diode array detection operated between 200 and $300 \mathrm{~nm}$. The internal standard was analysed 4 times for each set of extracted filters and was used to correct the variation in extraction solvent volumes due to the extracting procedure.

The biomass in units of chl a of the individual phytoplankton groups detected by the pigments was calculated by CHEMTAX v.1.95 (Mackey et al. 1996). The dataset of the natural samples was divided into 2 groups: samples with chl $a>10 \mu \mathrm{g} \mathrm{l}^{-1}(\mathrm{n}=25)$ and samples with chl $a<10 \mu \mathrm{gl}^{-1}(\mathrm{n}=42)$.

The initial pigment/chl a ratios used in the CHEMTAX program were from ML-treated cyanobacteria (see Table 1). ML pigment ratios were chosen as a compromise, since the samples were taken in $1 \mathrm{~m}$ depth, where light is reduced but usually not limiting for phytoplankton. ML ratios for the other phytoplankton groups developed for mesotrophic/eutrophic lakes were from Schlüter et al. (2006).

\section{RESULTS}

\section{Pigment/chl a ratios in cultures}

Chl $a$, zeaxanthin, myxoxanthophyll 2 , and $\beta$-carotene were present in all cultured strains while echinenone, canthaxanthin, and $\beta$-cryptoxanthin were present in most strains (Table 1). Furthermore, oscillaxanthin, aphanizophyll, nostoxanthin, caloxanthin, and myxoxanthophyll 1 were occasionally present. The ratios of the different pigments to chl a were 
Table 1. Average $(n=2)$ pigment/chl a ratios in the different species of cyanobacteria (strain codes added in parentheses, where applicable) grown in low light (LL), medium light (ML), high light (HL), or stationary growth (SG). syn.: synonymous. $\left({ }^{*}\right)$ trace amounts

\begin{tabular}{|c|c|c|c|c|c|c|c|c|c|c|c|}
\hline $\begin{array}{l}\text { Strain } \\
\text { Condition }\end{array}$ & $\begin{array}{l}\text { Oscilla- } \\
\text { xanthin }\end{array}$ & $\begin{array}{l}\text { Aphani- } \\
\text { zophyll }\end{array}$ & $\begin{array}{l}\text { Nosto- } \\
\text { xanthin }\end{array}$ & $\begin{array}{l}\text { Calo- } \\
\text { xanthin }\end{array}$ & $\begin{array}{c}\text { Myxo- } \\
\text { xantho- } \\
\text { phyll } 1\end{array}$ & $\begin{array}{c}\text { Myxo- } \\
\text { xantho- } \\
\text { phyll } 2\end{array}$ & $\begin{array}{c}\text { Zea- } \\
\text { xanthin }\end{array}$ & $\begin{array}{l}\text { Cantha- } \\
\text { xanthin }\end{array}$ & $\begin{array}{l}\beta \text {-crypto- } \\
\text { xanthin }\end{array}$ & $\begin{array}{c}\text { Echi- } \\
\text { nenone }\end{array}$ & $\begin{array}{c}\beta \text {-caro- } \\
\text { tene }\end{array}$ \\
\hline \multicolumn{12}{|c|}{ Dolichospermum circinale (syn. Anabaena circinalis) (K-1333) } \\
\hline LL & 0.004 & 0.087 & & & & 0.030 & 0.000 & 0.003 & & 0.038 & 0.086 \\
\hline ML & 0.027 & 0.260 & & & & 0.093 & 0.000 & 0.029 & & 0.067 & 0.060 \\
\hline HL & 0.044 & 0.371 & & & & 0.123 & 0.003 & 0.012 & & 0.042 & 0.055 \\
\hline $\mathrm{SG}$ & 0.020 & 0.233 & & & & 0.057 & 0.000 & 0.030 & & 0.066 & 0.051 \\
\hline \multicolumn{12}{|c|}{ Dolichospermum lemmermannii (syn. Anabaena lemmermannii) (K-0544) } \\
\hline LL & 0.001 & 0.019 & & & & 0.004 & & 0.018 & & 0.042 & 0.052 \\
\hline ML & 0.013 & 0.188 & & & & 0.073 & & 0.060 & & 0.071 & 0.062 \\
\hline HL & 0.005 & 0.077 & & & & 0.027 & & 0.057 & & 0.066 & 0.048 \\
\hline SG & 0.005 & 0.076 & & & & 0.016 & & 0.101 & & 0.088 & 0.061 \\
\hline \multicolumn{12}{|c|}{ Planktothrix sp. (327/2) } \\
\hline LL & 0.004 & & & & 0.014 & 0.041 & 0.168 & & * & 0.026 & 0.213 \\
\hline ML & 0.018 & & & & 0.099 & 0.103 & 0.422 & & * & 0.040 & 0.314 \\
\hline HL & 0.032 & & & & 0.186 & 0.202 & 0.825 & & * & 0.042 & 0.497 \\
\hline $\mathrm{SG}$ & 0.002 & & & & 0.047 & 0.135 & 0.527 & & * & 0.068 & 0.345 \\
\hline \multicolumn{12}{|c|}{ Planktothrix cf. agardhii (syn. Oscillatoria agardhii) (K-0546) } \\
\hline LL & 0.038 & & & & & 0.146 & 0.104 & & * & 0.052 & 0.181 \\
\hline ML & 0.149 & & & & & 0.467 & 0.224 & & * & 0.098 & 0.274 \\
\hline HL & 0.160 & & & & & 0.414 & 0.134 & & * & 0.081 & 0.231 \\
\hline SG & 0.242 & & & & & 0.781 & 0.395 & & * & 0.180 & 0.354 \\
\hline \multicolumn{12}{|c|}{ Planktothrix rubescens (syn. Oscillatoria rubescens) (K-0569) } \\
\hline LL & 0.030 & & & & & 0.115 & 0.134 & & * & 0.102 & 0.237 \\
\hline ML & 0.128 & & & & & 0.414 & 0.332 & & * & 0.155 & 0.301 \\
\hline HL & 0.629 & & & & & 1.399 & 0.721 & & * & 0.196 & 0.310 \\
\hline SG & 0.217 & & & & & 0.623 & 0.491 & & * & 0.180 & 0.272 \\
\hline \multicolumn{12}{|c|}{ Pseudanabaena sp. (K-1230) } \\
\hline LL & 0.013 & & & & & 0.007 & 0.262 & & * & 0.003 & 0.126 \\
\hline ML & 0.059 & & & & & 0.030 & 0.525 & & * & 0.009 & 0.147 \\
\hline HL & 0.097 & & & & & 0.045 & 0.649 & & * & 0.012 & 0.157 \\
\hline $\mathrm{SG}$ & 0.075 & & & & & 0.035 & 0.671 & & * & 0.016 & 0.163 \\
\hline \multicolumn{12}{|c|}{ Cylindrospermopsis raciborskii } \\
\hline LL & & 0.406 & & & & 0.039 & 0.003 & 0.008 & * & 0.126 & 0.095 \\
\hline ML & & 0.803 & & & & 0.098 & 0.003 & 0.012 & * & 0.178 & 0.115 \\
\hline $\mathrm{HL}$ & & 1.028 & & & & 0.134 & 0.002 & 0.019 & * & 0.166 & 0.104 \\
\hline SG & & 1.054 & & & & 0.088 & 0.003 & 0.012 & * & 0.241 & 0.116 \\
\hline \multicolumn{12}{|c|}{ Radiocystis sp., isolated in Brazilian reservoirs } \\
\hline LL & & & & & & 0.084 & 0.255 & 0.001 & * & 0.041 & 0.142 \\
\hline ML & & & & & & 0.343 & 0.497 & 0.003 & * & 0.041 & 0.169 \\
\hline HL & & & & & & 0.351 & 0.558 & 0.007 & * & 0.030 & 0.161 \\
\hline SG & & & & & & 0.391 & 0.444 & 0.015 & * & 0.104 & 0.261 \\
\hline \multicolumn{12}{|c|}{ Pseudanabaena sp., isolated in Brazilian reservoirs } \\
\hline LL & & & & & & 0.002 & 0.731 & * & * & & 0.122 \\
\hline ML & & & & & & 0.003 & 1.389 & * & * & & 0.128 \\
\hline HL & & & & & & 0.001 & 1.651 & * & * & & 0.135 \\
\hline SG & & & & & & 0.029 & 1.537 & * & * & & 0.138 \\
\hline \multicolumn{12}{|c|}{ Microcystis botrys (K-0967) } \\
\hline LL & & & 0.017 & 0.027 & & 0.069 & 0.027 & 0.003 & & 0.065 & 0.149 \\
\hline ML & & & 0.090 & 0.068 & & 0.290 & 0.074 & 0.013 & & 0.077 & 0.238 \\
\hline $\mathrm{HL}$ & & & 0.065 & 0.068 & & 0.381 & 0.124 & 0.019 & & 0.076 & 0.281 \\
\hline SG & & & 0.020 & 0.058 & & 0.069 & 0.111 & 0.005 & & 0.067 & 0.273 \\
\hline \multicolumn{12}{|c|}{ Microcystis aeruginosa (NIES-107) } \\
\hline LL & & & & & & 0.085 & 0.128 & 0.019 & * & 0.038 & 0.087 \\
\hline ML & & & & & & 0.297 & 0.256 & 0.038 & * & 0.063 & 0.098 \\
\hline $\mathrm{HL}$ & & & & & & 0.323 & 0.304 & 0.053 & * & 0.028 & 0.098 \\
\hline SG & & & & & & 0.472 & 0.428 & 0.033 & * & 0.112 & 0.202 \\
\hline
\end{tabular}


Table 1 (continued)

\begin{tabular}{|c|c|c|c|c|c|c|c|c|c|c|c|}
\hline $\begin{array}{l}\text { Strain } \\
\text { Condition }\end{array}$ & $\begin{array}{l}\text { Oscilla- } \\
\text { xanthin }\end{array}$ & $\begin{array}{l}\text { Aphani- } \\
\text { zophyll }\end{array}$ & $\begin{array}{l}\text { Nosto- } \\
\text { xanthin }\end{array}$ & $\begin{array}{c}\text { Calo- } \\
\text { xanthin }\end{array}$ & $\begin{array}{c}\text { Myxo- } \\
\text { xantho- } \\
\text { phyll } 1\end{array}$ & $\begin{array}{c}\text { Myxo- } \\
\text { xantho- } \\
\text { phyll } 2\end{array}$ & $\begin{array}{c}\text { Zea- } \\
\text { xanthin }\end{array}$ & $\begin{array}{l}\text { Cantha- } \\
\text { xanthin }\end{array}$ & $\begin{array}{l}\beta \text {-crypto- } \\
\text { xanthin }\end{array}$ & $\begin{array}{c}\text { Echi- } \\
\text { nenone }\end{array}$ & $\begin{array}{c}\beta \text {-caro- } \\
\text { tene }\end{array}$ \\
\hline \multicolumn{12}{|c|}{ Microcystis sp. (PCC-7820) } \\
\hline LL & & & & 0.068 & & 0.144 & 0.134 & 0.033 & * & 0.033 & 0.126 \\
\hline ML & & & & 0.162 & & 0.458 & 0.346 & 0.077 & * & 0.049 & 0.121 \\
\hline $\mathrm{HL}$ & & & & 0.124 & & 0.480 & 0.316 & 0.084 & * & 0.044 & 0.078 \\
\hline SG & & & & 0.203 & & 0.602 & 0.188 & 0.032 & ${ }^{*}$ & 0.075 & 0.082 \\
\hline \multicolumn{12}{|c|}{ Microcystis aeruginosa (K-0540) } \\
\hline LL & 0.006 & & & & & 0.100 & 0.114 & 0.015 & * & 0.035 & 0.127 \\
\hline ML & 0.038 & & & & & 0.353 & 0.276 & 0.038 & * & 0.067 & 0.139 \\
\hline $\mathrm{HL}$ & 0.044 & & & & & 0.385 & 0.318 & 0.057 & * & 0.080 & 0.175 \\
\hline SG & 0.075 & & & & & 0.041 & 0.669 & 0.000 & * & 0.019 & 0.167 \\
\hline \multicolumn{12}{|c|}{ Microcystis sp., isolated in Brazilian reservoirs } \\
\hline LL & & & & & & 0.075 & 0.177 & & * & 0.039 & 0.109 \\
\hline ML & & & & & & 0.215 & 0.165 & & * & 0.028 & 0.114 \\
\hline $\mathrm{HL}$ & & & & & & 0.207 & 0.328 & & * & 0.046 & 0.112 \\
\hline SG & & & & & & 0.031 & 0.079 & & * & 0.034 & 0.089 \\
\hline
\end{tabular}

affected by light intensity and most ratios increased from LL to HL, although some of the pigment ratios were relatively constant or even decreased at increased light, e.g. $\beta$-carotene/chl a in Dolichospermum circinale and Microcystis aeruginosa PCC7820 (Table 1). The pigment/chl a ratios of cultures, which had turned into SG phase, were generally within the range of ratios in the light treatment, but occasionally higher than those found for HL-treated cultures (Table 1).

\section{Toxin content in cultures}

In total, 5 of the cultured strains produced microcystins at concentrations above the detection limit of approx. $0.02 \mu \mathrm{g} \mathrm{l}^{-1}$ : Planktothrix cf. agardhii K-0546, $P$. rubescens K-0569, Microcystis aeruginosa NIES-107, Microcystis sp. PCC-7820, and the Microcystis sp. isolate from the Brazilian reservoirs. Eight different microcystins were detected: MC-LR, MC-YR, MC-RR, demethylated (DM) MC-LR, DM MC-RR, MC-LY, MC-LF and MC-LW. The density of the cultures varied slightly, and the concentration of the different microcystins is depicted in relation to chl a in order to compare the content of microcystins of the different strains (Fig. 2). MC-LR was the only toxin produced by all 5 strains. The relative content of microcystins generally increased from LL to HL and a further increase was seen for most microcystins in strains, which had turned into SG phase except for Microcystis sp. isolated from the Brazilian reservoirs, and for some of the MCs produced by Microcystis sp. PCC-7820.

\section{Phytoplankton in the reservoirs determined by pigments}

The pigment analyses of the natural samples revealed the presence of cyanobacteria detected by myxoxanthophyll 2, echinenone, and canthaxanthin in most samples, always zeaxanthin, and occasionally aphanizophyll and myxoxanthophyll 1. Chlorophytes (including euglenophytes) were detected by chl $b$, lutein, violaxanthin, and in most samples neoxanthin, and cryptophytes were revealed by alloxanthin. Fucoxanthin, chl $c_{1}$, and chl $c_{2}$ showed the presence of diatoms and possibly chrysophytes, while peridinin and 19'-hexanoyloxyfucoxanthin were occasionally detected in low concentrations showing some presence of dinoflagellates and haptophytes, respectively. The results from microscopy (see below) generally confirmed the presence of these groups. The zeaxanthin concentrations were relatively high in the reservoirs and myxoxanthophyll 2/zeaxanthin, echinenone/zeaxanthin, and canthaxanthin/zeaxanthin ratios were $0.28,0.14$, and 0.02 (average of all samples). The same ratios calculated for the cultured strains were generally much higher; on average up to $2.01,0.30$, and 0.11 , respectively (calculated from Table 1), which indicated that zeaxanthin-containing cyanobacteria without myxoxanthophyll, echinenone, and canthaxanthin, e.g. Synechococcus sp. (Schlüter et al. 2006, Descy 2017), were present in the reservoirs. Consequently, 7 phytoplankton groups were identified and loaded into the CHEMTAX program: cyanobacteria with echinenone, myxoxanthophyll 1, and zeaxanthin, 
P. rubescens $\mathrm{K}-0569$

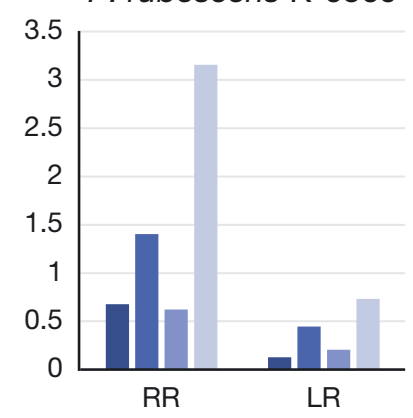

P. agardhii K-0546

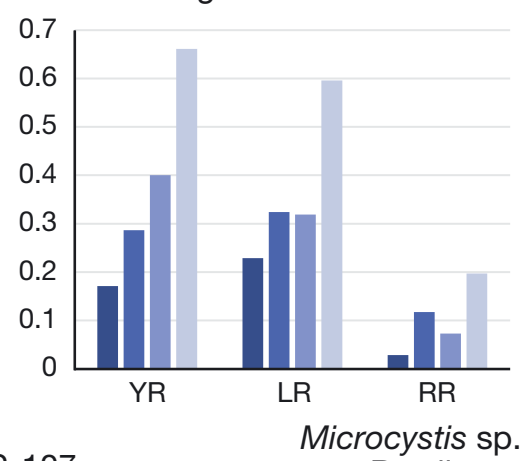

Brazil

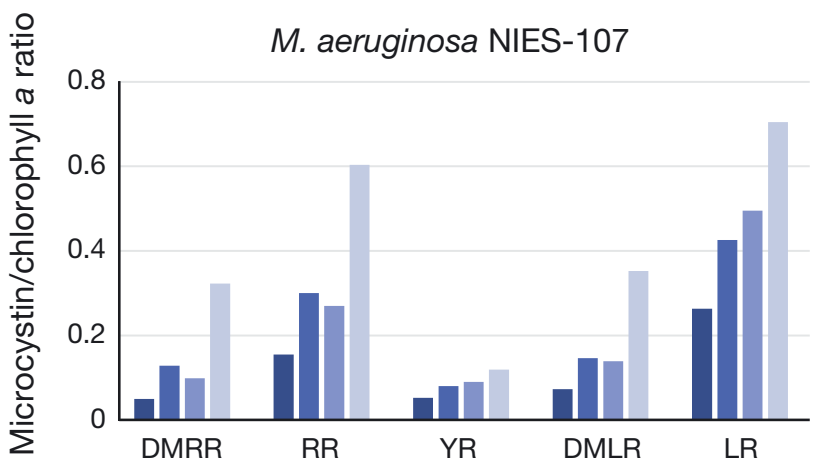

Microcystis sp. PCC-7820

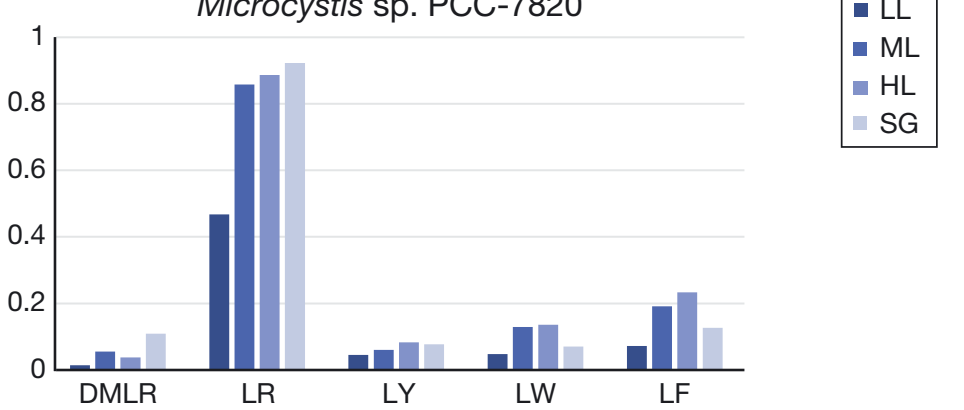

Fig. 2. Content of the different microcystins (LR, RR, YR, DMRR, DMLR, LY, LW, and LF; see 'Toxin content in cultures' for details) identified in the cultured strains of cyanobacteria (P.: Planktothrix; M.: Microcystis) in relation to chlorophyll a (growth conditions: LL: low light; ML: medium light; HL: high light, SG: stationary growth) which were mostly filamentous/colony-forming, and another group of cyanobacteria with zeaxanthin only, which were mostly coccoid/pico-sized.

Fish farms F1, F5, and F6 had a chl a biomass of $<10 \mu \mathrm{g} \mathrm{chl} \mathrm{a} \mathrm{l}^{-1}$ at all samplings, on average 3.6, 3.1,

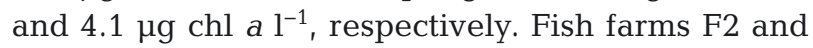
F3+F4 had markedly higher average chl a concentra-

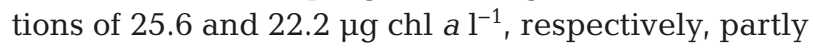
due to 2 diatom blooms in the spring of 2015 (Fig. 3). The CHEMTAX calculations showed that cyanobacteria generally dominated in all reservoirs during all seasons, except during the diatom spring bloom in F2 and F3+F4 (Fig. 3). However, in F6, chlorophytes tended to dominate when the total biomass was low- est in spring 2014 and autumn 2015. Cyanobacteria constituted on average $44 \%$ of the phytoplankton chl a biomass in F6 in all seasons (Table 2). In the remaining reservoirs, cyanobacteria constituted 62 to $65 \%$ of the chl a biomass (Table 2). If we disregard the diatom blooms, which seemed to be superimposed on the phytoplankton populations in spring 2015, cyanobacteria were on average 74 and $71 \%$ of the phytoplankton chl a biomass in F2 and F3+F4, respectively, which had the highest phytoplankton abundances. Regression analysis showed that cyanobacteria chl a biomass was significantly correlated with total chl a $(\mathrm{r}=0.38, \mathrm{p}$ $<$ 0.01). Apart from cyanobacteria, chlorophytes and cryptophytes were also generally always present and constituted an important fraction of the phytoplankton populations, particularly in the reservoirs with lower chl a concentrations. Dinoflagellates and haptophytes never attained significant biomasses in any of the reservoirs (Fig. 3).

\section{Microscopy identification of phytoplankton in the reservoirs}

The microscopy cell counting supported the findings that cyanobacteria in general were present at all samplings and reached high numbers of organisms, especially in F2, F3+F4, and F5 (Fig. 4). Beside the genera isolated from the reservoirs, more than 40 different species of cyanobacteria were identified including most of the cultured species, e.g. M. aeruginosa, Planktothrix sp., and Cylindrospermopsis raciborskii. Cryptophytes were generally also present in quite high numbers, especially in F1 and F6 (Fig. 4), with 2 species dominating: Cryptomonas brasiliensis and Rhodomonas lacustris. Furthermore, chlorophytes (including Zygnematophyceae, Euglenophyceae, and Trebouxiophyceae) were present in all reservoirs with more than 50 species identified, but the numbers of the individual species were often low. As found using the pigment method, diatoms were present in large numbers in spring 2015 in F2 and F3+F4 


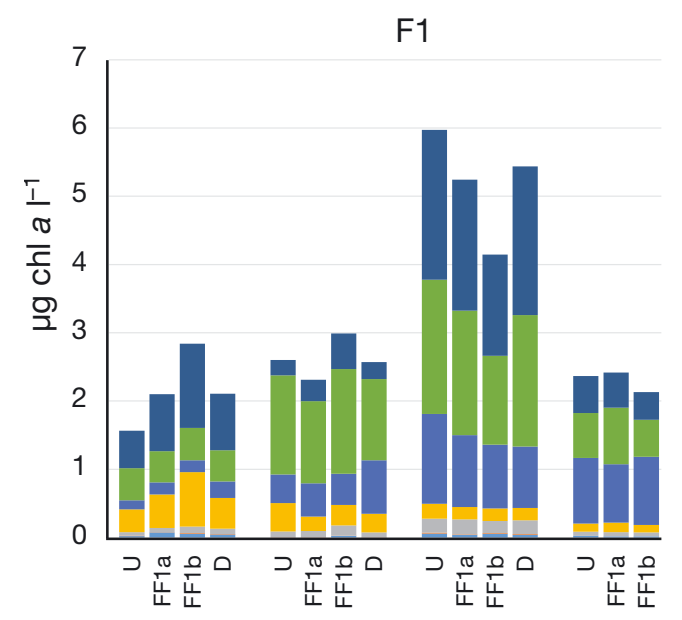

F5

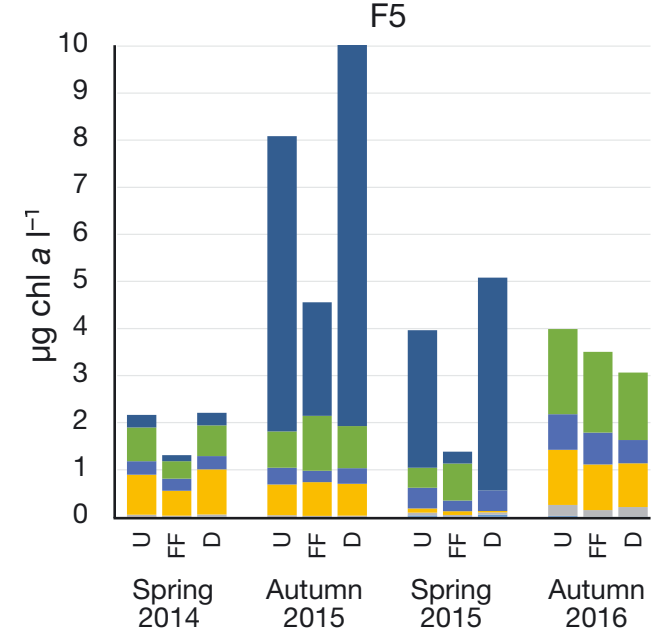

F2

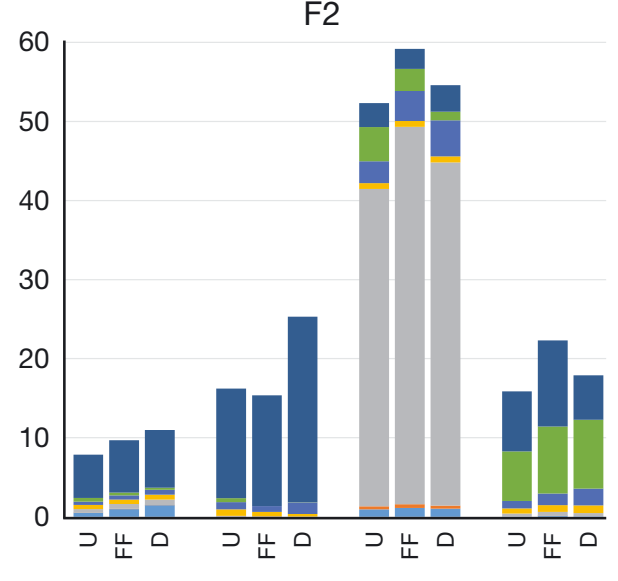

F6

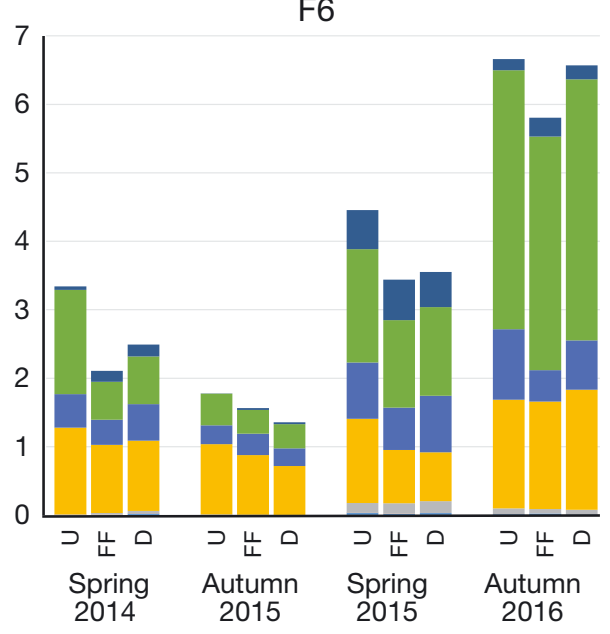

$\mathrm{F} 3+\mathrm{F} 4$

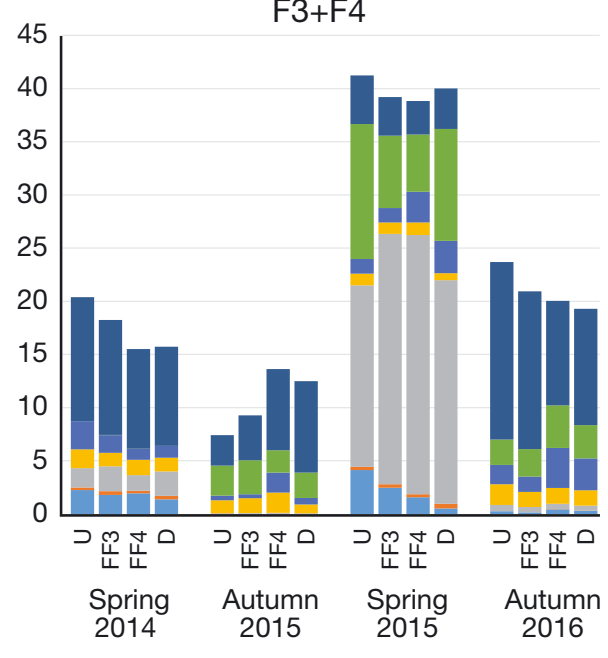

\begin{tabular}{|lc|}
\hline Cyanobacteria & Chlorophytes \\
(colony/filament) & Diatoms/ \\
Cyanobacteria & Chrysophytes \\
(coccoid/pico) & Haptophytes \\
Cryptophytes & Dinoflagellates \\
\hline
\end{tabular}

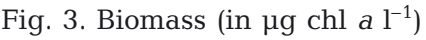
of phytoplankton groups determined by the pigment method at the different fish farms (F1 to F6, two farm areas, $1 \mathrm{a}$ and $1 \mathrm{~b}$, within F1) in the different seasons indicated below the $x$-axes. $\mathrm{U}$ : upstream; FF: fish farm; D: downstream
(Fig. 4) where Fragilaria sp. dominated. The chl a biomasses determined by the pigment method of cyanobacteria (sum of filamentous/colony forming and coccoid/pico-sized cyanobacteria), cryptophytes, chlorophytes, and diatoms were significantly correlated with the organism numbers of the respective groups counted in the microscope $(\mathrm{r}=0.52, \mathrm{p}<0.001$; $\mathrm{r}=0.46, \mathrm{p}<0.001 ; \mathrm{r}=0.38, \mathrm{p}<0.01$; and $\mathrm{r}=0.86, \mathrm{p}<$ 0.001 , respectively).

\section{Effect of fish farms on phytoplankton communities and toxin composition}

The fish farms affected the phytoplankton biomasses (determined by the pigment method) differently. In some sampling periods, total phytoplankton biomass was higher upstream, declined inside the fish farms and then increased downstream. This was observed for F5 in both autumn and spring 2015 and by both pigment analysis and microscopy (Figs. 3 $\& 4$ ), where particularly the colony forming/filamen- tous cyanobacteria decreased inside the fish farms. In fact, cyanobacteria were found to decrease inside the fish farms in most samplings (Table 2). However, statistical analyses ( $t$-test, paired samples) showed that the fish farms did not have a significant impact on the biomass nor the organism numbers of any of the phytoplankton groups (data not shown).

Microcystins were detected in all the reservoirs. MC-LR was typically the most abundant toxin and was present in all samples where microcystins were detected. An exception was fish farms F3+F4, where MC-RR was dominant in autumn 2016 (Fig. 5). In addition, MC-YR was generally also present. The total concentrations of microcystins were significantly correlated with the total chl a concentration of cyanobacteria ( $r=0.73, p<0.01$; Fig. 6). Furthermore, the total concentrations of microcystins were significantly correlated with the chl a biomasses of the filamentous/colony forming cyanobacteria $(\mathrm{r}=$ $0.70, \mathrm{p}<0.01$ ), and with the biomasses of coccoid/ pico-sized cyanobacteria, although with a weaker correlation $(r=0.26, p=0.039)$. 
Table 2. Percentage of cyanobacteria (both filamentous/ colony forming and coccoid/pico-sized) in relation to the total phytoplankton chl a biomass at the different fish farms (F1 to F6; two farm areas, $1 \mathrm{a}$ and $1 \mathrm{~b}$, within F1 given as 'Fish farm' and 'F1-1b', respectively). -: not applicable; na: not available

\begin{tabular}{|lcccccc|}
\hline Season & F1 & F2 & F3+F4 & F5 & F6 & Average \\
\hline Spring 2014 & & & & & & \\
Upstream & 65 & 76 & 57 & 45 & 47 & 58 \\
Fish farm & 62 & 72 & 59 & 38 & 34 & 53 \\
F1-1b & 60 & - & 60 & - & - & 60 \\
Downstream & 61 & 69 & 59 & 41 & 35 & 53 \\
Autumn 2015 & & & & & & \\
Upstream & 64 & 89 & 77 & 87 & 26 & 69 \\
Fish farm & 66 & 91 & 80 & 79 & 24 & 68 \\
F1-1b & 69 & - & 71 & - & - & 70 \\
Downstream & 56 & 93 & 88 & 90 & 28 & 71 \\
Spring 2015 & & & & & & \\
Upstream & 70 & 14 & 42 & 84 & 50 & 52 \\
Fish farm & 71 & 9 & 27 & 75 & 54 & 47 \\
F1-1b & 67 & - & 22 & - & - & 45 \\
Downstream & 75 & 8 & 36 & 89 & 51 & 52 \\
Autumn 2016 & & & & & & \\
Upstream & 51 & 87 & 81 & 45 & 59 & 65 \\
Fish farm & 56 & 87 & 83 & 47 & 64 & 67 \\
F1-1b & 45 & - & 69 & - & - & 57 \\
Downstream & na & 80 & 73 & 49 & 61 & 66 \\
Average & 62 & 65 & 62 & 64 & 44 & 60 \\
& & & & & & \\
\hline
\end{tabular}

\section{DISCUSSION}

\section{Cyanobacteria in Brazilian water reservoirs}

The most common freshwater bloom-forming cyanobacteria genera in Brazil are Microcystis, Dolichospermum, Aphanizomenon, Planktothrix, and Cylindrospermopsis (de Carvalho et al. 2008). Among these, toxic cyanobacteria have been shown to be represented by more than 30 species (Sant'Anna et al. 2008). Many of these toxic species were detected in the different reservoirs with fish farms in the present study. Besides the 3 cyanobacteria isolated in the reservoirs (Radiocystis sp., Pseudanabaena sp., and Microcystis sp.; Table 1), all the cultured genera were detected in the reservoirs.

\section{Pigments for chemotaxonomic analysis}

Ideally, pigment ratios for the CHEMTAX program for calculating the chl a biomasses of the individual groups should be obtained from cultures collected at the study site (Higgins et al. 2011). Because of this, pigment/chl a ratios were determined here for both known cyanobacterial genera in the Brazilian reser- voirs (which were isolated and cultured) as well as for the new isolates from reservoirs (Table 1), since cyanobacteria were overall the most abundant group in the reservoirs. The pigment content and pigment/ chl a ratios of the cultured cyanobacteria were within the range of earlier studies of other species of freshwater cyanobacteria (Schlüter et al. 2006, Lauridsen et al. 2011). Pigment/chl a ratios were affected by the growth conditions, especially light intensity. The ratios increased from low to high light (Table 1) and confirm that the carotenoids of cyanobacteria are part of the light protection of the photosynthetic apparatus in the cells (Takaichi \& Mochimaru 2007, Mehnert et al. 2012). Apart from $\beta$-carotene and zeaxanthin, all pigments identified in the different strains of cyanobacteria are diagnostic pigments specific to cyanobacteria: echinenone, canthaxanthin, myxoxanthophyll 1 and 2 (2 myxol glycosides, where the sugar moieties have not been determined; Takaichi \& Mochimaru 2007), aphanizophyll, etc. (Table 1). For chemotaxonomy, these specific pigments are valuable since determination of the presence of cyanobacteria based on the pigment compositions becomes conclusive.

Echinenone and myxoxanthophyll 2 are the most important pigments for detecting cyanobacteria in freshwater, because they occur in all the cultured cyanobacteria and are universally detected in many other species of cyanobacteria (Goodwin 1980, Rowan 1989, Roy et al. 2011). However, the coccoid/ pico-sized cyanobacteria (e.g. Synechococcus sp.) only contain zeaxanthin (Schlüter et al. 2006, Descy 2017). When coccoid/pico-sized cyanobacteria are abundant, the zeaxanthin concentration may dominate the cyano-pigment composition and indicate a high abundance of these cyanobacteria, as found in the present study. Especially in F1 and F6, when chl a biomasses were low, these cyanobacteria constituted an important fraction of the cyanobacteria.

\section{Pigment analysis versus microscopy for characterization of phytoplankton communities}

The abundance of cyanobacteria and other phytoplankton groups, determined by the pigment method, correlated significantly with organism number per volume determined by microscopy. However, each cyanobacteria colony/filament was counted as a single organism, despite the fact that chains and colonies were often present, and therefore chl a biomasses and organism numbers will not necessarily correlate. The results from the 2 methods in Figs. 3 \& 4 

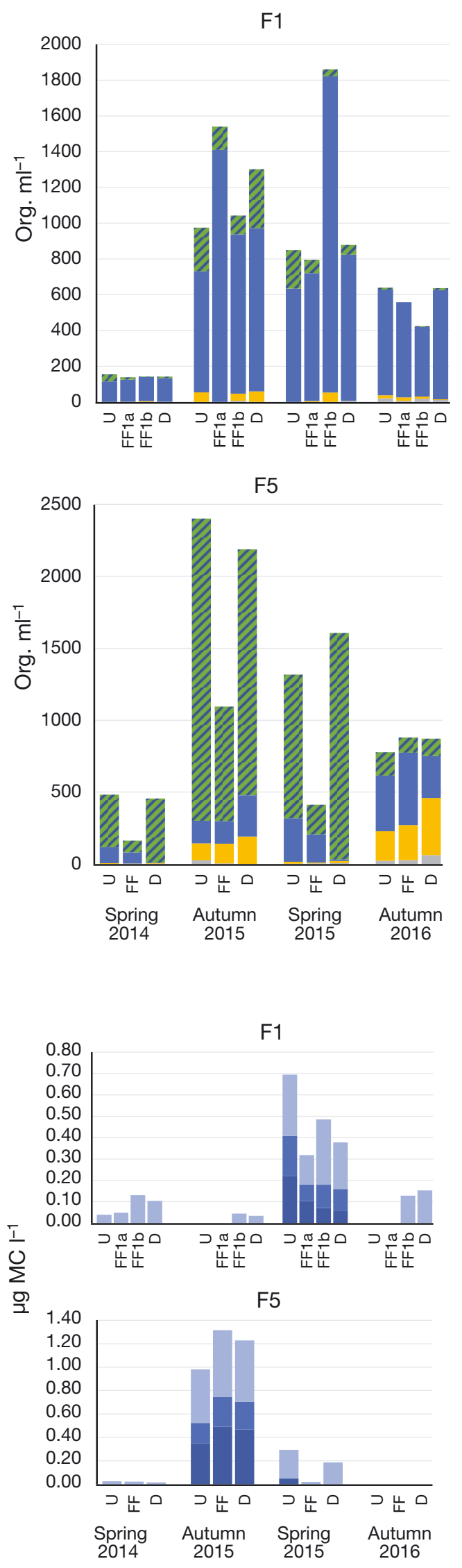
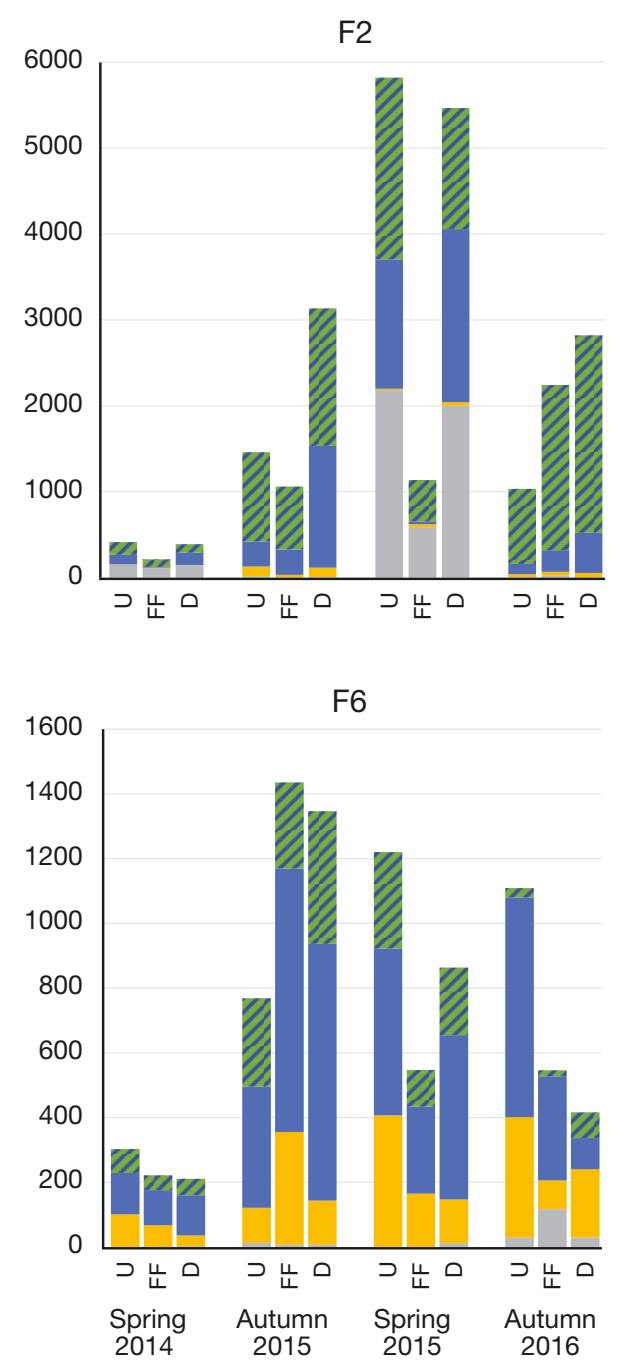

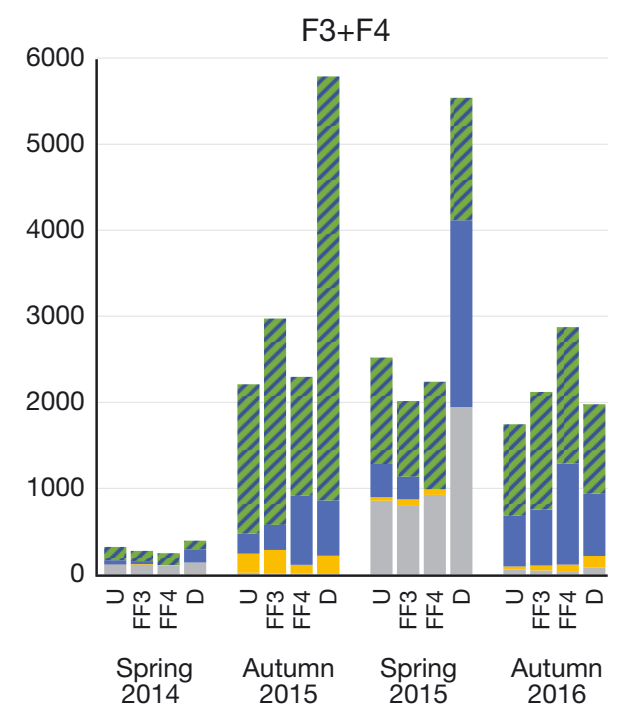

a Cyanobacteria

- Cryptophytes

$\because$ Chlorophytes

- Diatoms/Chrysophytes

- Dinoflagellates

Fig. 4. Organism numbers (org. $\mathrm{ml}^{-1}$ ) counted by microscope at the different fish farms (F1 to F6; two farm areas, $1 \mathrm{a}$ and $1 \mathrm{~b}$, within $\mathrm{F} 1$ ) in the different seasons indicated below the $x$-axes. $U$ : upstream; FF: fish farm; D: downstream
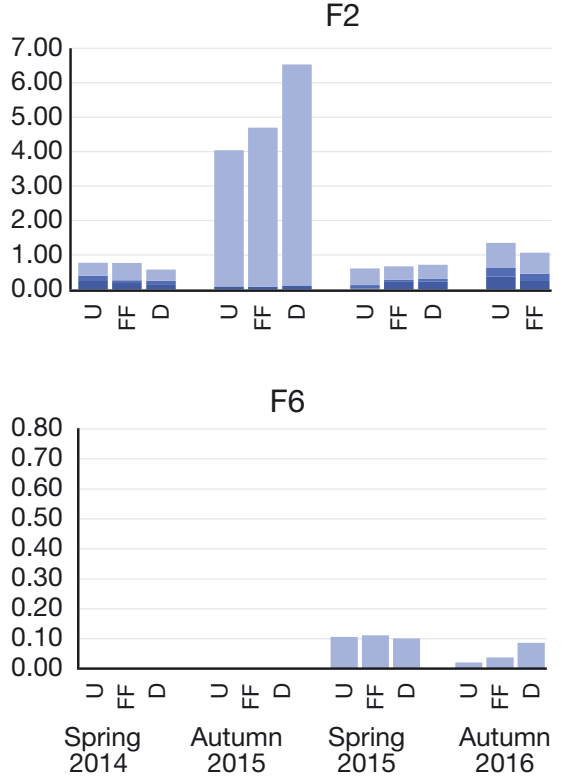

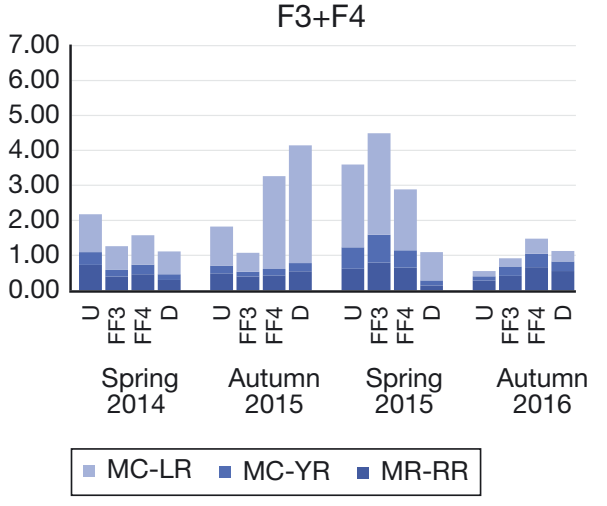

Fig. 5. Concentrations of different microcystins (MC) at the different fish farms (F1 to F6; two farm areas, $1 \mathrm{a}$ and $1 \mathrm{~b}$, within $\mathrm{F} 1$ ) in the different seasons indicated below the $x$-axes. U: upstream; FF: fish farm; D: downstream 


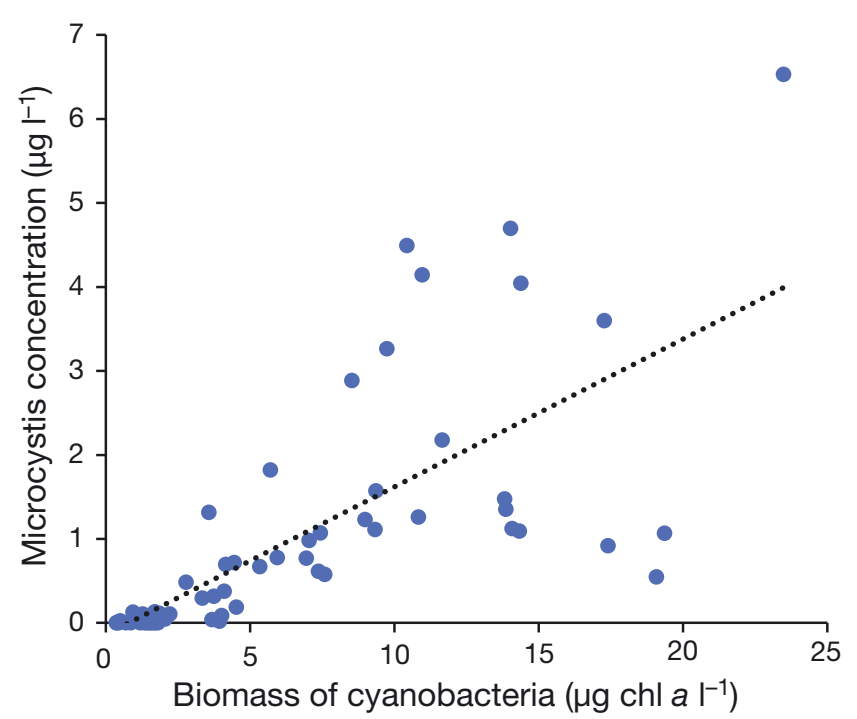

Fig. 6. Total microcystin concentration as function of total biomass of cyanobacteria (filamentous/colony forming and coccoid/pico-sized cyanobacteria) in $\mu \mathrm{g} \mathrm{chl} \mathrm{al^{-1 }}$

occasionally became uncoupled due to the inconsistent relationship between organism numbers and chl a for the different groups. Cryptophytes determined by microscopy seemed to be the largest group, especially in the 2 reservoirs with low chl a (F1 and F6), when determined by microscopy (Fig. 4). The 2 dominating species in these reservoirs, Cryptomonas brasiliensis and Rhodomonas lacustris, are single cells of a relatively small size, 6 to $10 \mu \mathrm{m}$, which have been found to dominate in turbulent and oligotrophic environments of other Brazilian reservoirs (Rosini et al. 2016). Furthermore, the most abundant diatom (Fragilaria sp.) found in F2 and F3+F4 forms colonies of many cells, which caused a discrepancy in organism numbers and chl a biomass of the diatoms (Figs. $3 \& 4$ ).

Unlike microscopy, pigment analyses by HPLC have the advantage of being fast and reproducible, and taxonomical expertise is not required. Furthermore, all phytoplankton cells, including the picosized cells that cannot be identified using standard microscopy methods (e.g. inverted microscopy as applied in the present study), are included by the pigment method (Zapata 2005). Because small and overlooked species may be ignored by microscopy, actual species diversity may be more accurately determined by pigment analysis. This was confirmed by analysis of phytoplankton species in more than 40 lakes, where a higher Shannon's diversity index was determined by pigment analyses than by microscopy counting (Schlüter et al. 2016). An additional advan- tage of the pigment method is that rare species in low densities can be identified but may be overlooked by microscopy. In the present study, minor concentrations of diagnostic pigments from haptophytes and dinoflagellates, 19'-hexanoyloxy-fucoxanthin and peridinin, were occasionally detected using the pigment method, showing that few cells from these groups were present (Fig. 3), but they were not detected in the smaller volume examined under the microscope.

\section{Identification of single species by pigment analysis}

Typically, the HPLC method is considered applicable for determining only groups or classes of phytoplankton, but in a few cases the method has been used to determine presence of species. For example, the toxic species of cyanobacteria in the Baltic Sea, Nodularia spumigena, contains a rare and unique pigment, 4-keto-myxoxanthophyll, which can be used as a diagnostic pigment for the early warning of blooms of this cyanobacterium in the Baltic Sea (Schlüter et al. 2004). Likewise, the pigment gyroxanthin-diester has been shown to be a useful diagnostic pigment for the toxic dinoflagellate Karenia brevis forming large blooms in coastal areas (Millie et al. 1997, Örnólfsdóttir et al. 2003). In the present study, both the microcystin-producing and the nonmicrocystin-producing strains of cyanobacteria contained the pigments myxoxanthophyll 2 and echinenone, as well as other cyanobacteria pigments, but none of these diagnostic pigments were found to indicate presence of microcystins.

\section{Cyanobacterial dominance in phytoplankton in the Brazilian reservoirs}

In eutrophic temperate lakes, cyanobacteria usually dominate the phytoplankton community (Watson et al. 1997, Søndergaard et al. 2005), and this seems to be even more pronounced in subtropical and tropical areas, where bloom-forming cyanobacteria can proceed at relatively lower nutrient input rates and concentrations (Kosten et al. 2012, Pearl \& Paul 2012). In the studied Brazilian reservoirs, cyanobacteria constituted an increasing abundance of the phytoplankton populations at increasing chl a biomass (Table 2, Fig. 3); up to $75 \%$ of the chl a biomass in F2 and F3+F4 could be related to cyanobacteria, if disregarding the diatom blooms encountered in spring 2015. The abundance of cyanobacteria co- 
varied with the concentration of microcystin in the water, as confirmed by the positive correlation between concentrations of $\mathrm{chl} a$ and microcystins (Fig. 6) showing that with an increasing abundance of cyanobacteria, the risk of toxin-producing cyanobacteria increases. Furthermore, our pigment analyses indicated that the microcystin concentrations could be ascribed mainly to the filamentous/colonyforming cyanobacteria in the reservoirs.

\section{Cyanobacterial toxins versus fish health}

Total phytoplankton biomasses, and especially the biomasses of the filamentous/colony forming cyanobacteria in the reservoirs, were often higher upstream, then declined inside the fish farms, and frequently increased again downstream (Fig. 3). A decline inside the fish farms indicates that the fish intendedly or unintendedly grazed on phytoplankton, i.e. phytoplankton accidentally consumed with fish feed pellets (Smith et al. 2008). Tilapia is a planktivorous species that has been shown to inevitably ingest microcystin when microcystin-producing cyanobacteria are present; the microcystins tend to accumulate in the liver, viscera, and muscle tissue of the fish (Magalhães et al. 2001, Mohamed et al. 2003, Zhao et al. 2006). Several studies have reported accumulation of the hepatotoxin in edible tissues at levels that exceed WHO guidelines for tolerable daily intake of $0.04 \mathrm{\mu g} \mathrm{kg}^{-1}$ body weight $\mathrm{d}^{-1}$ (WHO 1998), assuming that 100 to $300 \mathrm{~g}$ of fresh weight tissue is consumed. This suggests that human intoxication is plausible (Smith et al. 2008).

Tilapia feeding on natural phytoplankton have been shown to accumulate microcystin in liver and muscle tissue even at concentrations below $1 \mu \mathrm{g} \mathrm{l}^{-1}$ (Deblois et al. 2008). In the present reservoirs, concentrations of microcystin frequently exceeded this concentration (up to $6.5 \mu \mathrm{g} \mathrm{l}^{-1}$ was found in F2 and $\mathrm{F} 3+\mathrm{F} 4)$, suggesting that tilapia in the farms potentially accumulated microcystin. However, statistical tests showed that the cyanobacterial biomass was not reduced during passage of water in the farms, suggesting absence or minor intake of cyanobacteria by tilapia (Table 2). This was supported by lack of declining concentrations of microcystin downstream of the farms (Fig. 5). The actual concentrations of microcystin and other cyanotoxins in the fish were not determined in this study. It is possible that because the fish were fed in the cages, the intake of cyanotoxins in the farms may have been low, but that would require further analyses.

\section{Microcystin production by cultures}

Five of the cyanobacteria cultured produced different microcystins (Fig. 2), and MC-LR, which is the most common microcystin (Dawson 1998), was always present. Besides MC-LR, the most common microcystins detected were MC-RR and MC-YR at 14 different locations in Finland (Spoof et al. 2003), which agrees with the findings in the present study. Several of the cultured species did not produce microcystins, although they have previously been reported to produce microcystin, e.g. Dolichospermum circinale, Microcystis botrys and $M$. aeruginosa (Sant'Anna et al. 2008). For Microcystis, this observation may reflect that natural populations can include phenotypically identical toxic and non-toxic genotypes (Kurmayer et al. 2002, Ouellette et al. 2006). Light intensity may also control the toxin production. For example, Kaebernick et al. (2000) found increased levels of microcystin transcripts under illumination with $>31 \mu \mathrm{mol}$ photons $\mathrm{m}^{-2} \mathrm{~s}^{-1}$. This light dependence of microcystin production was confirmed in the present study, where the relative amount of microcystins (MC/chl a) generally increased from LL (approx. $4 \mu \mathrm{mol}$ photons $\mathrm{m}^{-2} \mathrm{~s}^{-1}$ ) to HL (Fig. 2). When the growth turned into the SG phase due to nutrient limitation, MCs/chl a were often higher than when nutrients were not limiting, indicating that the microcystin production is also controlled by nutritional conditions. This is supported by previous observations, although contradictory results on the influence of nutrients on microcystin production have been reported (Neilan et al. 2013, Boopathi \& Ki 2014), and shows that the toxin production is difficult to predict and is influenced by many factors.

\section{Early warning of toxic cyanobacteria}

There is an increasing need to detect presence of toxin-producing cyanobacteria at an early stage (Codd et al. 2005). Here, the significant relationship between microcystins and the chl a biomass of cyanobacteria showed that the pigment method could detect toxic cyanobacteria in the Brazilian reservoirs. At low chl a levels and when the phytoplankton populations were diverse and pigments showed that chlorophytes and cryptophytes comprised a relatively large part of the phytoplankton, the concentrations of microcystin were generally low. When the chl a biomass of cyanobacteria exceeded $4 \mu \mathrm{g} \mathrm{l}^{-1}$, microcystins were always present, and at approx. $6 \mu \mathrm{g}$ cyanobacterial chl a $\mathrm{l}^{-1}$ the concentra- 
tion of microcystins exceeded $1 \mu \mathrm{g} \mathrm{l} \mathrm{l}^{-1}$ (WHO limit for the content of MC-LR in drinking water; WHO 1998). This microcystin concentration corresponds to a total chl a concentration of approx. $12 \mu \mathrm{g} \mathrm{l}^{-1}$ (calculated from the regression of total chl $a$ as function of chl $a$ of cyanobacteria). This is close to the level of $10 \mu \mathrm{g}$ chl $a l^{-1}$, which the WHO has proposed as the level for the low probability of adverse health effects from contact with, or ingestion or inhalation of cyanobacteria. Moderate, high, and very high risk levels

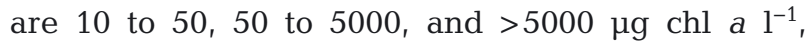
respectively (Chorus \& Bartram 1999).

In the reservoirs, cyanobacteria did not always dominate at high chl a concentrations, and diatoms were responsible for the instances where chl a reached

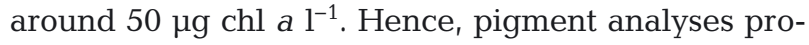
vided additional and valuable information on the potential risk of toxic cyanobacteria. For early warning of toxic cyanobacteria in freshwater reservoirs, for example used for aquaculture production, pigment analyses can provide fast and reliable results on the presence of cyanobacteria and help predict emerging incidents of toxic cyanobacteria in the water.

Acknowledgements. This work was funded by The Danish Council for Strategic Research (IMPCON project; grant 3050-00008A) and FAPESP (grant 2013/50504-5). Merete Allerup is thanked for skillful technical assistance and we are grateful to Jennifer Oakley for linguistic corrections.

\section{LITERATURE CITED}

Bicudo CEM, Menezes M (2017) Gêneros de algas de águas continentais do Brasil: chave para identificação e descrições, $3^{\text {rd }}$ edn. Rima, São Carlos

Boopathi T, Ki JS (2014) Impact of environmental factors on the regulation of cyanotoxin production. Toxins 6 : 1951-1978

Briand JF, Jacquet S, Bernard C, Humbert JF (2003) Health hazards for terrestrial vertebrates from toxic cyanobacteria in surface water ecosystems. Vet Res 34:361-377

Chorus I, Bartram J (eds) (1999) Toxic cyanobacteria in water. E \& FN Spon, London

* Codd GA, Morrison LF, Metcalf JS (2005) Cyanobacterial toxins: risk management for health protection. Toxicol Appl Pharmacol 203:264-272

de Carvalho LR, Pipole F, Werner VR, Laughinghouse IV and others (2008) A toxic cyanobacterial bloom in an urban coastal lake, Rio Grande do Sul state, southern Brazil. Braz J Microbiol 39:761-769

Dawson RM (1998) The toxicology of microcystins. Toxicon 36:953-962

* Deblois CP, Aranda-Rodriguez R, Giani A, Bird DF (2008) Microcystin accumulation in liver and muscle of tilapia in two large Brazilian hydroelectric reservoirs. Toxicon 51: 435-448

Descy JP (2017) Estimation of cyanobacteria biomass by marker pigment analysis. In: Meriluoto J, Spoof L, Codd
GA (eds) Handbook of cyanobacterial monitoring and cyanotoxin analysis. John Wiley \& Sons, Chichester, p 342-349

Eriksson JE, Meriluoto JAO, Lindholm T (1989) Accumulation of a peptide toxin from the cyanobacterium Oscillatoria agardhii in the freshwater mussel Anodonta cygnea. Hydrobiologia 183:211-216

Goodwin TW (1980) The biochemistry of the carotenoids, $2^{\text {nd }}$ edn. Vol 1: Plants. Chapman and Hall, London

Gurbuz F, Uzunmehmetoğlu OY, Diler O, Metcalf JS, Codd GA (2016) Occurrence of microcystins in water, bloom, sediment and fish from a public water supply. Sci Total Environ 562:860-868

*Hauser-Davis RA, Lavradas RT, Lavandier RC, Rojas EGA, Guarino AWS, Ziolli RL (2015) Accumulation and toxic effects of microcystin in tilapia (Oreochromis niloticus) from an eutrophic Brazilian Lagoon. Ecotoxicol Environ Saf 112:132-136

Higgins WH, Wright SW, Schlüter L (2011) Quantitative interpretation of chemotaxonomic pigment data. In: Roy S, Llewellyn CA, Egeland ES, Johnsen G (eds) Phytoplankton pigments: characterization, chemotaxonomy and applications in oceanography. Cambridge University Press, Cambridge, p 257-313

Kaebernick M, Neilan BA, Börner T, Dittmann E (2000) Light and the transcriptional response of the microcystin biosynthesis gene cluster. Appl Environ Microbiol 66: 3387-3392

Kosten S, Huszar V, Bécares E, Costa L and others (2012) Warmer climate boosts cyanobacterial dominance in shallow lakes. Glob Change Biol 18:118-126

*Kurmayer R, Dittmann E, Fastner J, Chorus I (2002) Diversity of microcystin genes within a population of the toxic cyanobacterium Microcystis spp. in Lake Wannsee (Berlin, Germany). Microb Ecol 43:107-118

₹Lauridsen TL, Schlüter L, Johansson LS (2011) Determining algal assemblages in oligotrophic lakes and streams: comparing information from newly developed pigment/ chlorophyll a ratios with direct microscopy. Freshw Biol 56:1638-1651

Lund JWG, Kipling C, Legren ED (1958) The invert microscope method of estimating algal numbers and the statistical basis of estimations by counting. Hydrobiologia 11: 143-170

*Mackey MD, Mackey DJ, Higgins HW, Wright SW (1996) CHEMTAX - a program for estimating class abundance from chemical markers: application to HPLC measurements of phytoplankton. Mar Ecol Prog Ser 144:265-283

Magalhães VF, Soares RM, Azevedo SMFO (2001) Microcystin contamination in fish from the Jacarepagu'a Lagoon (Rio de Janeiro, Brazil): ecological implication and human health risk. Toxicon 39:1077-1085

*Malbrouck C, Kestemont P (2006) Effects of microcystins on fish. Environ Toxicol Chem 25:72-86

*Mehnert G, Rücker J, Nicklisch A, Leunert F, Wiedner C (2012) Effects of thermal acclimation and photoacclimation on lipophilic pigments in an invasive and a native cyanobacterium of temperate regions. Eur J Phycol 47: 182-192

Meriluoto J Spoof L, Codd GA (eds) (2017) Handbook of cyanobacterial monitoring and cyanotoxin analysis. John Wiley \& Sons, Chichester

Millie DF, Schofield OM, Kirkpatrick GJ, Johnsen G, Tester PA, Vinyard BT(1997) Detection of harmful algal blooms using photopigments and absorption signatures: a case 
study of the Florida red tide dinoflagellate, Gymnodinium breve. Limnol Oceanogr 42:1240-1251

Mohamed ZA, Carmichael WW, Hussein AA (2003) Estimation of microcystins in the freshwater fish Oreochromis niloticus in an Egyptian fish farm containing a Microcystis bloom. Environ Toxicol 18:137-141

Neilan BA, Pearson LA, Muenchhoff J, Moffitt MC, Dittmann E (2013) Environmental conditions that influence toxin biosynthesis in cyanobacteria. Environ Microbiol 15:1239-1253

O'Neil JM, Davis TW, Burford MA, Gobler CJ (2012) The rise of harmful cyanobacteria blooms: the potential roles of eutrophication and climate change. Harmful Algae 14: 313-334

Örnólfsdóttir EB, Pinckney JL, Tester PA (2003) Quantification of the relative abundance of the toxic dinoflagellate, Karenia brevis (Dinophyta), using unique photopigments. J Phycol 39:449-457

Ouellette AJA, Handy SM, Wilhelm SW (2006) Toxic microcystis is widespread in Lake Erie: PCR detection of toxin genes and molecular characterization of associated cyanobacterial communities. Microb Ecol 51:154-165

Paerl HW, Paul VJ (2012) Climate change: links to global expansion of harmful cyanobacteria. Wat Res 46: 1349-1363

Rosini EF, Tucci A, do Carmo CF, Rojas NET, de Barros HP, Mallasen M (2016) Changes in phytoplankton spatial and temporal dynamics in a Brazilian tropical oligotrophic reservoir after net cage installation. Braz J Bot 39: 569-581

Rowan KS (1989) Photosynthetic pigments of algae. Cambridge University Press, Cambridge

Roy S, Llewellyn CA, Egeland ES, Johnsen G (2011) Phytoplankton pigments: characterization, chemotaxonomy and applications in oceanography. Cambridge University Press, Cambridge

Sant'Anna CL, Azevedo MTP, Sormus L (1989) Fitoplâncton do Lago das Garças, Parque Estadual das Fontes do Ipiranga, São Paulo, SP, Brasil: estudo taxonômico e aspectos ecológicos. Hoehnea 16:89-131

Sant'Anna CL, Azevedo MTP, Werner VR, Dogo CR, Rios FR, de Carvalho LR (2008) Review of toxic species of cyanobacteria in Brazil. Algol Stud 126:251-265

Schlüter L, Garde K, Kaas H (2004) Detection of the toxic cyanobacteria Nodularia spumigena by means of a 4 keto-myxoxanthophyll-like pigment in the Baltic Sea. Mar Ecol Prog Ser 275:69-78

Schlüter L, Lauridsen TL, Krogh G, Jørgensen T (2006) Identification and quantification of phytoplankton groups in lakes using new pigment ratios - a comparison between pigment analysis by HPLC and microscopy. Freshw Biol 51:1474-1485

Schlüter L, Behl S, Striebel M, Stibor H (2016) Comparing microscopic counts and pigment analyses in 46 phytoplankton communities from lakes of different trophic state. Freshw Biol 61:1627-1639

Smith JL, Haney JF (2006) Foodweb transfer, accumulation, and depuration of microcystins, a cyanobacterial toxin, in pumpkinseed sunfish (Lepomis gibbosus). Toxicon 48: 580-589

Smith JL, Boyer GL, Zimba PV (2008) A review of cyanobacterial odorous and bioactive metabolites: impact and management alternatives in aquaculture. Aquaculture 280:5-20

Soares RM, Magalhaes VF, Azevedo SM (2004) Accumula- tion and depuration of microcystins (cyanobacteria hepatotoxins) in Tilapia rendalli (Cichlidae) under laboratory conditions. Aquat Toxicol 70:1-10

Søndergaard M, Jeppesen E, Jensen JP, Amsinck SL (2005) Water Framework Directive: ecological classification of Danish lakes. J Appl Ecol 42:616-629

* Spoof L, Vesterkvist P, Lindholm T, Meriluoto J (2003) Screening for cyanobacterial hepatotoxins, microcystins and nodularin in environmental water samples by reverse-phase liquid chromatography-electrospray ionization mass spectrometry. J Chromatogr A 1020: 105-119

K Spoof L, Neffling MR, Meriluoto J (2010) Fast separation of microcystins and nodularins on narrow bore reversedphase columns coupled to a conventional HPLC system. Toxicon 55:954-964

* Takaichi S, Mochimaru M (2007) Carotenoids and carotenogenesis in cyanobacteria: unique ketocarotenoids and carotenoid glycosides. Cell Mol Life Sci 64:2607-2619

Tucci A, Sant'Anna CL, Gentil RC, Azevedo MTP (2006) Fitoplâncton do Lago das Garças, São Paulo, Brasil: um reservatório urbano eutrófico. Hoehnea 33:147-175

* Ueno Y, Nagata S, Tsutsumi T, Hasegawa A, and others (1996) Detection of microcystins, a blue-green algal hepatotoxin, in drinking water sampled in Haimen and Fusui, endemic areas of primary liver cancer in China, by highly sensitive immunoassay. Carcinogenesis 17 : 1317-1321

UNESCO (2010) Microscopic and molecular methods for quantitative phytoplankton analysis. IOC Manuals and Guides, No. 55. Intergovernmental Oceanographic Commission of UNESCO, Paris

Utermöhl H (1958) Zur Vervollkommnung der quantitativen Phytoplankton-Methodik. Mitt Int Ver Theor Angew Limnol 9:1-38

*Van Heukelem L, Thomas CS (2001) Computer-assisted high-performance liquid chromatography method development with applications to the isolation and analysis of phytoplankton pigments. J Chromatogr A 910:31-49

*Watson SB, McCauley E, Dowing JA (1997) Patterns in phytoplankton taxonomic composition across temperate lakes of different nutrient status. Limnol Oceanogr 42: 487-495

WHO (World Health Organization) (1998) Guidelines for drinking-water quality, $2^{\text {nd }}$ edn, addendum to Vol 2. Health criteria and other supporting information. WHO, Geneva

* Willén W, Ahlgren G, Tilahun G, Spoof L, Neffling M, Meriuolota J (2011) Cyanotoxin production in seven Ethiopian Rift Valley lakes. Inland Waters 1:81-91

*Wright SW, Thomas DP, Marchant HJ, Higgins HW, Mackey MD, Mackey DJ (1996) Analysis of phytoplankton of the Australian sector of the Southern Ocean: comparisons of microscopy and size frequency data with interpretations of pigment HPLC data using the 'CHEMTAX' matrix factorisation program. Mar Ecol Prog Ser 144:285-298

Zapata M (2005) Recent advances in pigment analysis as applied to picophytoplankton. Vie Milieu 55:233-248

Z Zhao M, Xie S, Zhu X, Yang Y, Gan N, Song L (2006) Effect of dietary cyanobacteria on growth and accumulation of microcystins in Nile tilapia (Oreochromis niloticus). Aquaculture 261:960-966

* Zhou L, Yu H, Chen K (2002) Relationship between microcystin in drinking water and colorectal cancer. Biomed Environ Sci 15:166-171 